\title{
Protein Kinase $C \delta$ Regulates Ethanol Intoxication and Enhancement of GABA-Stimulated Tonic Current
}

\author{
Doo-Sup Choi, ${ }^{1}$ Weizheng Wei, ${ }^{2}$ J. Kevin Deitchman, ${ }^{1}$ Viktor N. Kharazia, ${ }^{1}$ Heidi M. B. Lesscher, ${ }^{1}$ Thomas McMahon, ${ }^{1}$ \\ Dan Wang, ${ }^{1}$ Zhan-Heng Qi, ${ }^{1}$ Werner Sieghart, ${ }^{3}$ Chao Zhang, ${ }^{4}$ Kevan M. Shokat, ${ }^{4}$ Istvan Mody, ${ }^{2}$ and Robert 0. Messing ${ }^{1}$ \\ ${ }^{1}$ Ernest Gallo Clinic and Research Center, Department of Neurology, University of California, San Francisco, Emeryville, California 94608, ${ }^{2}$ Department of \\ Neurology, David Geffen School of Medicine, University of California at Los Angeles, Los Angeles, California 90095, ${ }^{3}$ Division of Biochemistry and \\ Molecular Biology, Centre for Brain Research, Medical University of Vienna, A-1090 Vienna, Austria, and ${ }^{4}$ Department of Cellular and Molecular \\ Pharmacology and the Howard Hughes Medical Institute, University of California, San Francisco, San Francisco, California 94143
}

Ethanol alters the distribution and abundance of PKC $\delta$ in neural cell lines. Here we investigated whether PKC $\delta$ also regulates behavioral responses to ethanol. $\mathrm{PKC} \delta^{-1-}$ mice showed reduced intoxication when administered ethanol and reduced ataxia when administered the nonselective $\mathrm{GABA}_{\mathrm{A}}$ receptor agonists pentobarbital and pregnanolone. However, their response to flunitrazepam was not altered, suggesting that $\mathrm{PKC} \delta$ regulates benzodiazepine-insensitive $\mathrm{GABA}_{\mathrm{A}}$ receptors, most of which contain $\delta$ subunits and mediate tonic inhibitory currents in neurons. Indeed, the distribution of $\mathrm{PKC} \delta$ overlapped with $\mathrm{GABA}_{\mathrm{A}} \delta$ subunits in thalamus and hippocampus, and ethanol failed to enhance tonic GABA currents in $\mathrm{PKC} \delta^{-I-}$ thalamic and hippocampal neurons. Moreover, using an ATP analog-sensitive PKC $\delta$ mutant in mouse $\mathrm{L}\left(\mathrm{tk}^{-}\right)$fibroblasts that express $\alpha 4 \beta 3 \delta \mathrm{GABA}_{\mathrm{A}}$ receptors, we found that ethanol enhancement of GABA currents was $\mathrm{PKC} \delta$-dependent. Thus, PKC $\delta$ enhances ethanol intoxication partly through regulation of $\mathrm{GABA}_{\mathrm{A}}$ receptors that contain $\delta$ subunits and mediate tonic inhibitory currents. These findings indicate that PKC $\delta$ contributes to a high level of behavioral response to ethanol, which is negatively associated with risk of developing an alcohol use disorder in humans.

Key words: protein kinase C; ethanol; GABA; tonic current; intoxication; extrasynaptic

\section{Introduction}

$\mathrm{GABA}_{\mathrm{A}}$ receptors are the main inhibitory neurotransmitter receptors in the brain and are a major target for sedative-hypnotic drugs, including ethanol (Mehta and Ticku, 1999). Although ethanol can enhance the function of $\mathrm{GABA}_{\mathrm{A}}$ receptors, the importance of this effect for mediating behavioral responses to ethanol in addition to anesthesia has remained controversial (Criswell and Breese, 2005; Weiner and Valenzuela, 2006). Recently, several laboratories have reported that mild to moderately intoxicating concentrations of ethanol (3-30 mM) enhance tonic GABA currents in neurons (Wei et al., 2004; Fleming et al., 2007; Liang et al., 2008) and in heterologous systems expressing $\alpha 4 \beta \delta$ receptors (Sundstrom-Poromaa et al., 2002; Wallner et al., 2003), which form extrasynaptic $\mathrm{GABA}_{\mathrm{A}}$ receptors that mediate tonic inhibitory currents in neurons (Glykys and Mody, 2007). These results suggest that enhancement of tonic GABA currents con-

\footnotetext{
Received July 3, 2008; revised Sept. 3, 2008; accepted Sept. 29, 2008.

This work was supported by funds provided by the State of California for medical research on alcohol and substance abuse through the University of California at San Francisco, Contract W81XWH-07-1-0078 from the U.S Department of the Army and National Institutes of Health (NIH) Grant AA013588 to R.0.M., NIH Grant Al44099 to K.M.S., and NIH Grant NS30549 and the Coelho Endowment to I.M. We thank S. Taylor and J. Connolly for maintaining and genotyping the mouse colony.

Correspondence should be addressed to Dr. Robert 0. Messing, Ernest Gallo Clinic and Research Center, 5858 Horton Street, Suite 200, Emeryville, CA 94608. E-mail: romes@gallo.ucsf.edu.

D.S.C.'s present address: Mayo Clinic College of Medicine, Department of Molecular Pharmacology and Experimental Therapeutics, Rochester, MN 55905.

DOI:10.1523/JNEUROSCI.3156-08.2008

Copyright $\odot 2008$ Society for Neuroscience $\quad$ 0270-6474/08/2811890-10 $\$ 15.00 / 0$
}

tributes to pharmacological effects of ethanol observed during social drinking. However, this conclusion has been challenged by recent studies that could not replicate these findings (Borghese et al., 2006; Yamashita et al., 2006). The basis for this discrepancy is not known.

Recently, we found that phosphorylation plays a critical role in altering the sensitivity of synaptic $\mathrm{GABA}_{\mathrm{A}}$ receptors to ethanol. Synaptic receptors mediate phasic inhibitory currents in neurons, and instead of $\delta$ subunits, contain $\gamma 2$ subunits, which target the receptors to the synapse (Glykys and Mody, 2007). Using receptors comprised of $\alpha 1 \beta 2 \gamma 2$ subunits, we found that protein kinase $\mathrm{C}(\mathrm{PKC}) \varepsilon$-mediated phosphorylation of $\gamma 2$ subunits reduces ethanol enhancement of receptor function (Qi et al., 2007). This finding raised the possibility that phosphorylation also regulates GABA-stimulated tonic currents carried by receptors containing $\delta$ subunits.

Previous studies using gene-targeted mice have demonstrated that two members of the protein kinase C (PKC) family, PKC $\gamma$ and $\mathrm{PKC} \varepsilon$, reciprocally modulate behavioral responses to ethanol. Mice that lack PKC $\gamma$ show reduced signs of ethanol intoxication and consume more ethanol than wild type mice (Harris et al., 1995; Bowers et al., 1999; Bowers and Wehner, 2001), whereas mice lacking PKC $\varepsilon$ show increased signs of ethanol intoxication (Hodge et al., 1999) and decreased ethanol self-administration (Hodge et al., 1999; Olive et al., 2000). In NG108-15 neuroblastoma-glioma cells, acute exposure to ethanol alters the subcellular localization of a third PKC isozyme, PKC $\delta$ (Gordon 
et al., 1997), and in PC12 cells, chronic ethanol exposure increases the abundance of this isozyme (Messing et al., 1991). These in vitro studies suggest that $\mathrm{PKC} \delta$ is important for cellular responses to ethanol. It is not yet known, however, whether PKC $\delta$ regulates behavioral or cellular responses to ethanol in vivo.

Here we investigated whether PKC $\delta$ is important for effects of ethanol on behavior and neuronal function using mice that lack $\mathrm{PKC} \delta$, which we generated by homologous recombination in embryonic stem cells (Chou et al., 2004). We report a series of behavioral, anatomical, pharmacological, and electrophysiological studies, that together show that $\mathrm{PKC} \delta$ is required for full expression of ethanol intoxication and for ethanol enhancement of GABA-stimulated tonic inhibitory currents in neurons.

\section{Materials and Methods}

$P K C \delta^{-/-}$mice. $\mathrm{PKC} \delta^{-1-}$ mice were generated on a $\mathrm{C} 57 \mathrm{BL} / 6 \mathrm{~J} \times 129 \mathrm{X} 1 /$ SvJ background as described previously (Chou et al., 2004). Chimeric mice were bred with $\mathrm{C} 57 \mathrm{BL} / 6 \mathrm{~J}$ mice to generate $\mathrm{F} 1$ hybrids, which were intercrossed to generate F2 hybrid ( 50\% C57BL/6J and 50\% 129X1/ SvJ) littermates for experiments. Mice were housed in standard Plexiglas cages with rodent chow and water available ad libitum. The colony room was maintained on a $12 \mathrm{~h}$ light/dark cycle with lights on at 6:00 A.M. Only male mice were used for experiments when they reached $\sim 10$ weeks of age. The Gallo Center Institutional Animal Care and Use Committee approved animal care and handling procedures in accord with NIH guidelines and Policies on the Use of Animals and Humans in Neuroscience Research as approved by the Society for Neuroscience.

Animal behavior. Ethanol-induced ataxia was evaluated using a mouse rotarod treadmill (Ugo Basile) set to a fixed speed of $20 \mathrm{rpm}$ (Dar, 1997). Mice received an intraperitoneal injection of ethanol $[20 \%(\mathrm{v} / \mathrm{v})$ with isotonic saline], and then tested for latency to fall from the rotarod every 15 min over a 60 min period. The animals were used only once in this experiment. Ethanol-induced hypothermia was examined by measuring rectal temperature using a type J thermocouple (Barrant, Barrington, IL) at room temperature $\left(22 \pm 0.5^{\circ} \mathrm{C}\right)$ before and after an intraperitoneal injection of $4 \mathrm{~g} / \mathrm{kg}$ ethanol (20\% (v/v) with isotonic saline). Rectal temperature was assessed every $30 \mathrm{~min}$ up to $120 \mathrm{~min}$ after ethanol administration. The duration of the loss of righting reflex (LORR) and plasma ethanol clearance were examined as described (Choi et al., 2002). Other behavioral studies are described in the supplemental Methods available at www.jneurosci.org as supplemental material.

Histology. Mice were anesthetized with pentobarbital $(80 \mathrm{mg} / \mathrm{kg})$ and perfused via the aorta with 4\% paraformaldehyde (Sigma-Aldrich) in phosphate buffer $(\mathrm{PB})$. Brains were removed and postfixed for $2-4 \mathrm{~h}$ in the same fixative at $4^{\circ} \mathrm{C}$. For immunoperoxidase studies, brains were immersed in 30\% sucrose for $24 \mathrm{~h}$, frozen, and cut in $35 \mu \mathrm{m}$ sections using a sliding microtome (Leica). Free-floating sections were incubated in 3\% hydrogen peroxide in PBS for $10 \mathrm{~min}$ followed by $50 \%$ alcohol for $20 \mathrm{~min}$, and then 10\% normal donkey serum in PBS for $30 \mathrm{~min}$, followed by primary goat polyclonal antibody recognizing the $\mathrm{C}$ terminus of rat PKC $\delta$ (1:1000-1500) (Santa Cruz Biotechnology) overnight. Sections were then incubated in 2\% normal donkey serum in PBS for $10 \mathrm{~min}$ followed by biotinylated secondary donkey anti-goat antibody (1:300) (Jackson ImmunoResearch) for $2 \mathrm{~h}$ and then ExtrAvidin-peroxidase complex $(1: 3,000)$ (Sigma-Aldrich) for $2 \mathrm{~h}$. Peroxidase was histochemically visualized with diaminobenzidine. Control experiments omitting primary antibody resulted in lack of immunostaining, and specificity of the primary antibody was confirmed by absence of immunoreactivity in brain sections from $\mathrm{PKC} \delta^{-1-}$ mice.

Slice electrophysiology. Tonic and phasic inhibitory currents were recorded as previously described (Stell et al., 2003; Wei et al., 2004) in slices prepared from $\mathrm{PKC} \delta^{-1-}$ and $\mathrm{PKC} \delta^{+/+}$littermates (40- to 60 -d-old). An examiner blinded to the genotype of the slice performed the recordings. The artificial CSF contained (in $\mathrm{mm}$ ): $126 \mathrm{NaCl}, 2.5 \mathrm{KCl}, 2 \mathrm{CaCl}_{2}, 2$ $\mathrm{MgCl}_{2}, 1.25 \mathrm{NaH}_{2} \mathrm{PO}_{4}, 26 \mathrm{NaHCO}_{3}, 10-25$ D-glucose, $0.005 \mathrm{GABA}$, and 3 kynurenic acid at a $\mathrm{pH}=7.3-7.4$ when bubbled with $95 \% \mathrm{O}_{2} / 5 \% \mathrm{CO}_{2}$. Whole-cell recordings were made from neurons identified by IR video- microscopy (Versascope; E. Marton Electronics) using pipettes filled with (in mM) $125 \mathrm{CsCl}, 5 \mathrm{NaCl}, 2 \mathrm{MgCl}_{2}, 10$ Hepes, 0.1 EGTA, $2 \mathrm{Na}$-ATP, $0.5 \mathrm{Na}-\mathrm{GTP}$, and $5 \mathrm{QX}-314$ (pH: 7.25, 280-290 mOsm). The amount of tonic current was measured as described (Stell et al., 2003) by subtracting the current in the presence of saturating concentrations of SR 95531. IPSCs were detected and analyzed using LabVIEW-based software (National Instruments).

$P K C \delta$ assay. PKC $\delta$ was expressed and purified as described previously (Allen et al., 2007). Kinase activity was measured by fluorescence polarization as described (Qi et al., 2007) using $4 \mathrm{ng}$ of native PKC $\delta$ or $8 \mathrm{ng}$ of as-PKC $\delta, 2.5 \mu \mathrm{M}$ ATP, and 0.012-2.0 × 10 5 nM 1-naphtyl-4-amino-5(4-methylphenyl)-7-( $t$-butyl)pyrazolo[3,4- $d]$ pyrimidine (1NaPP1). Reaction mixtures were incubated for $90 \mathrm{~min}$ at $27^{\circ} \mathrm{C}$.

Electrophysiology in $L\left(t k^{-}\right)$cells. Whole-cell patch clamp recordings were made on $\mathrm{L}\left(\mathrm{tk}^{-}\right)$cells that either stably express both as-PKC $\delta$ and $\alpha 4 \beta 3 \delta \mathrm{GABA}_{\mathrm{A}}$ receptors (see supplemental Methods available at www. jneurosci.org as supplemental material), or only $\alpha 4 \beta 3 \delta \mathrm{GABA}_{\mathrm{A}}$ receptors (Brown et al., 2002). Cells were plated on a $35 \mathrm{~mm}$ Petri dish, which was placed in a recording chamber on the stage of an IX71 Olympus inverted microscope. The recording electrodes were pulled from borosilicate glass capillary tubing (Garner Glass) using a micropipette puller (P-97) (Sutter Instruments). The resistances of the electrodes were 5-8 $\mathrm{M} \Omega$ when filled with pipette solution containing (in $\mathrm{mm}$ ): $145 \mathrm{~N}$-methylD-glucamine (NMDG)-Cl, $1 \mathrm{MgCl}_{2}, 10 \mathrm{HEPES}$, and $4 \mathrm{Mg}^{2+}$-ATP, 2 $\mathrm{Na}^{+}$-ATP ( $\mathrm{pH} 7.3$, adjusted with $\mathrm{HCl}$ ). The external solution used to perfuse the cells continuously during the experiment contained (in $\mathrm{mm}$ ): $145 \mathrm{NaCl}, 3 \mathrm{KCl}, 2 \mathrm{CaCl}_{2}, 1 \mathrm{MgCl}_{2}, 10 \mathrm{HEPES}, 10 \mathrm{D}$-glucose, and 20 D-sucrose ( $\mathrm{pH} 7.4$, adjusted with $\mathrm{NaOH})$.

The procedures used to test GABA and ethanol sensitivity were similar to those previously described (Qi et al., 2007). To test the effect of inhibiting $\mathrm{PKC} \delta$ on $\mathrm{GABA}_{\mathrm{A}}$ receptor function, cells were incubated with external solution containing $10 \mu \mathrm{M} 1 \mathrm{NaPP} 1$ or vehicle $(0.1 \% \mathrm{DMSO})$ for 30 min before stimulation with GABA. Cells were then voltage-clamped at $-75 \mathrm{mV}$ and the GABA dose-response relationship was determined in the presence or absence of $10 \mu \mathrm{M} 1 \mathrm{NaPP} 1$. The response to ethanol was then assessed by coapplication of ethanol with an $\mathrm{EC}_{20}$ concentration of GABA using a Perfusion Fast-Step SF-77B system (Warner Instruments) driven by pClamp 9 software (Axon CNS-Molecular Devices). There was a 1-min washout period between each drug application. Whole-cell currents were recorded using an Axopatch 200B patch amplifier (Axon CNS-Molecular Devices), filtered at $2 \mathrm{kHz}$, and digitized at $5 \mathrm{kHz}$ with a Digidata 1322A interface and pClamp 9 software. The serial resistance was monitored continuously during each experiment, and data from cells that showed a $>30 \%$ change in resistance were discarded. All recordings were obtained at $27^{\circ} \mathrm{C}$.

Statistical analysis. Unless otherwise noted, results are expressed as mean \pm SEM values for the indicated number of experiments. Data were examined by unpaired, two-tailed $t$ tests, or ANOVA, and differences between means were considered significant when $p<0.05$. ANOVA for repeated measures was used when testing for the effects of drugs pre and postethanol in slice electrophysiology experiments. Chi-square analysis was used to determine whether inheritance of the mutant allele deviated from a Medelian pattern and to detect a difference in survival between $\mathrm{PKC} \delta^{-1-}$ and $\mathrm{PKC} \delta^{+/+}$mice. Nonlinear regression analysis was used to determine $\mathrm{IC}_{50}$ values for kinase inhibition by $1 \mathrm{NaPP} 1$.

\section{Results}

\section{Normal baseline behavior in $\mathrm{PKC} \delta^{-/-}$mice}

$\mathrm{PKC} \delta^{-1-}$ mice displayed normal reproductive behavior. At weaning, 919 offspring of heterozygous breeding pairs showed a Mendelian pattern of inheritance with $258(28.0 \%) \mathrm{PKC}^{+/+}$, $443(48.2 \%) \mathrm{PKC} \delta^{+/-}$, and 218 (23.7\%) PKC $\delta^{-1-}$ mice $\left(\chi^{2}=\right.$ $2.247, \mathrm{df}=2, p=0.325)$. The spontaneous mortality rates were similar for PKC $\delta^{-/-}(1.83 \%)$ and $\mathrm{PKC} \delta^{+/+}(1.16 \%)$ mice maintained for at least 6 weeks $\left(\chi^{2}=0.003, p=0.95\right)$. The brains of $\mathrm{PKC} \delta^{-1-}$ mice showed no gross anatomical abnormalities, evidence of abnormal neuronal migration, loss or overabundance of neurons, or gliosis (data not shown). Water consumption was 

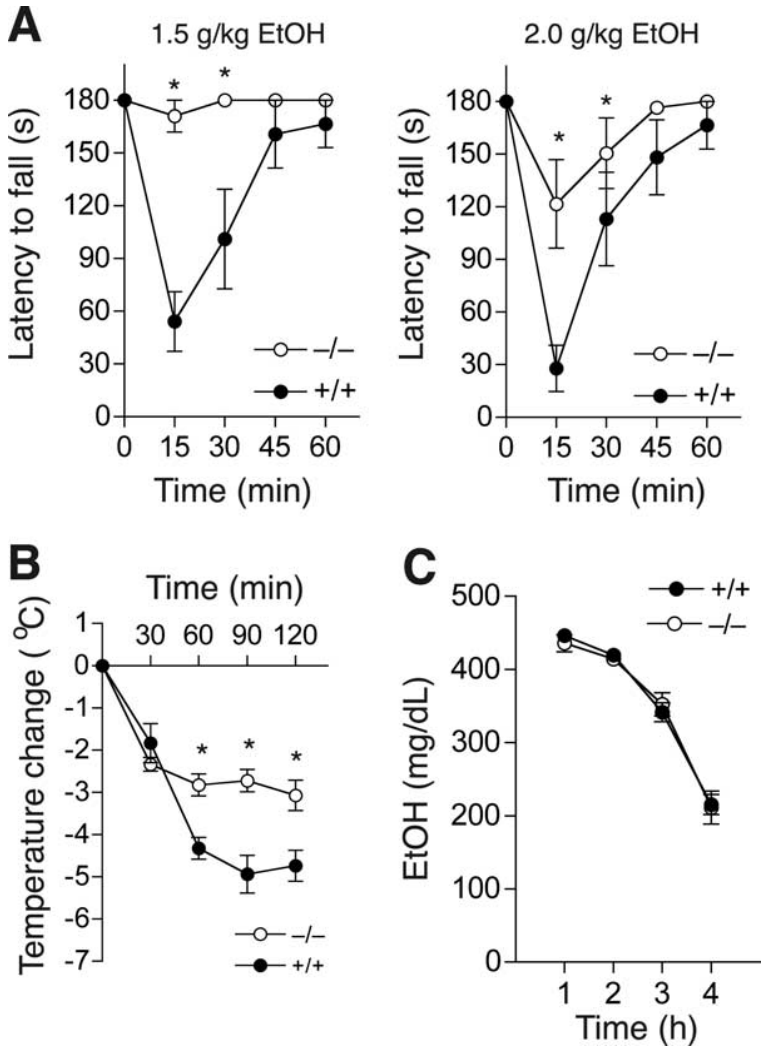

Figure 1. Acute responses to ethanol in $\mathrm{PKC} \delta^{-1-}$ mice. $A$, Ethanol induced much more ataxia in PKC $\delta^{+/+}$mice compared with PKC $\delta^{-1-}$ mice ( $n=8$ for each genotype; ${ }^{*} p<0.05$ compared with PKC $\delta^{+/+}$mice at the same time by Tukey's tests). $\boldsymbol{B}$, Ethanol-induced hypothermia was greater in PKC $\delta^{+/+}$mice compared with PKC $\delta^{-1-}$ mice $(n=8$ for each genotype; ${ }^{*} p<0.05$ compared with PKC $\delta^{+/+}$mice at the same time by Tukey's tests). C, Blood ethanol clearance after administration of $4.0 \mathrm{~g} / \mathrm{kg}$ ethanol was similar in both genotypes ( $n=$ 12 for each genotype).

similar among wild type and $\mathrm{PKC} \delta^{-1-}$ mice (supplemental Fig. $1 A$, available at www.jneurosci.org as supplemental material). Strength, locomotor activity, and coordination were also similar between the genotypes (supplemental Fig. $1 B-F$, available at www.jneurosci.org as supplemental material). Therefore baseline motor function was not altered by deletion of PKC $\delta$.

Diminished acute responses to ethanol in $\mathrm{PKC} \delta^{-1-}$ mice To study the role of PKC $\delta$ in the acute effects of intoxicating concentrations of ethanol, we examined ethanol-induced ataxia using a constant velocity rotarod (Rustay et al., 2003). PKC $\delta^{-/-}$ mice remained on the rotarod much longer than wild type littermates when administered 1.5 or $2.0 \mathrm{~g} / \mathrm{kg}$ ethanol (Fig. $1 A$ ). Twoway, repeated measures ANOVA showed main effects of genotype $\left(F_{(1,56)}=14.58, p=0.002\right)$ and time $\left(F_{(4,56)}=12.77, p<\right.$ $0.001)$, and an interaction between these factors $\left(F_{(4,56)}=9.92\right.$, $p<0.001)$ with $1.5 \mathrm{~g} / \mathrm{kg}$ ethanol. Similarly, there were main effects of genotype $\left(F_{(1,56)}=5.52, p<0.034\right)$, and time $\left(F_{(4,56)}=\right.$ 19.98, $p<0.001)$, and an interaction between these factors $\left(F_{(4,56)}=3.47, p<0.013\right)$ at $2.0 \mathrm{~g} / \mathrm{kg}$ ethanol.

We next examined responses to higher, hypnotic doses of ethanol by measuring ethanol-induced hypothermia and ethanolinduced loss of the righting reflex (LORR). Basal body temperature was similar in $\mathrm{PKC} \delta^{-1-}\left(37.88 \pm 0.17^{\circ} \mathrm{C}, n=8\right)$ and $\mathrm{PKC} \delta^{+/+}$mice $\left(37.44 \pm 0.16^{\circ} \mathrm{C}, n=8 ; p=0.086\right)$. However, when administered $4.0 \mathrm{~g} / \mathrm{kg}$ ethanol, $\mathrm{PKC} \delta^{-1-}$ mice developed less severe hypothermia than $\mathrm{PKC} \delta^{+/+}$mice (Fig. $1 B$ ). Two-way, repeated measures ANOVA showed effects of genotype $\left(F_{(1,56)}=\right.$ $19.68, p<0.001)$ and time $\left(F_{(4,56)}=66.62, p<0.001\right)$, and an interaction between these factors $\left(F_{(4,56)}=8.06, p<0.001\right)$. The duration of the LORR was also reduced $(p=0.034)$ in $\mathrm{PKC} \delta^{-/-}$ mice $(48.8 \pm 5.8 \mathrm{~min} ; n=8)$ compared with $\mathrm{PKC} \delta^{+/+}$littermates $(78.0 \pm 11.3 \mathrm{~min} ; n=7)$ after acute administration of ethanol.

Because differential absorption, distribution, or clearance of ethanol could contribute to altered acute responses, we measured blood ethanol concentrations $1-4 \mathrm{~h}$ after intraperitoneal injection of $4.0 \mathrm{~g} / \mathrm{kg}$ ethanol. We found that blood ethanol concentrations did not differ between the genotypes during this time period (Fig. 1C). Thus, absence of PKC $\delta$ diminishes the ataxic, hypothermic, and hypnotic effects of ethanol by altering the nervous system response to ethanol rather than by altering ethanol clearance.

\section{PKC $\delta$ expression in mouse brain}

The resistance of $\mathrm{PKC} \delta^{-1-}$ mice to ethanol-induced ataxia led us to investigate whether $\mathrm{PKC} \delta$ is expressed in brain regions that control motor function. To determine where in the brain PKC $\delta$ is expressed, we identified $\mathrm{PKC} \delta$ immunoreactivity in brain sections from PKC $\delta^{+/+}$mice (Fig. $2 A, C-I$ ). We examined sections from $\mathrm{PKC} \delta^{-1-}$ mice to identify nonspecific immunoreactivity (Fig. $2 B$ ). We found that $\mathrm{PKC} \delta$ was most abundant in thalamic neurons (Fig. $2 A, C$ ), including those of ventromedial, ventrolateral, and ventroanterior thalamic nuclei, which receive fibers from the cerebellum, pallidum, and substantia nigra, and send projections to the motor cortex (Paxinos, 1995). Strong PKC $\delta$ immunoreactivity was also found in thalamocortical fibers in layers I, IV, and VI of the neocortex (Fig. 2A,D). In the cerebellum, PKC $\delta$ immunoreactivity was detected in fibers of inhibitory basket cells contacting Purkinje cells whereas Purkinje cells overall displayed low to medium levels of $\mathrm{PKC} \delta$ immunoreactivity. Lower levels of PKC $\delta$ were present in pyramidal neurons, dentate granule cells, and molecular layer interneurons of the hippocampus (Fig. 2 F), in the central amygdala, and, to a lesser extent, the basolateral amygdala (Fig. 2G). There were some areas of light PKC $\delta$ immunoreactivity in the caudate-putamen (Fig. $2 A A-H$ ), but none in the nucleus accumbens (Fig. $2 H$ ) or the ventral tegmental area (Fig. 2I). Therefore, mouse PKC $\delta$ is mainly expressed in cerebellar and thalamocortical circuits, and to a lesser extent in the hippocampus and central amygdala.

\section{Diminished ataxic response to $\mathrm{GABA}_{\mathrm{A}}$ receptor agonists in PKC $\boldsymbol{\delta}^{-/-}$mice}

To investigate molecular mechanisms that explain why ethanolinduced ataxia is reduced in $\mathrm{PKC} \delta^{-1-}$ mice, we used pharmacological agents to examine receptors previously implicated in ethanol-induced incoordination (Lüddens et al., 1990; Fidecka and Langwínski, 1995; Khanna et al., 1995; Grobin et al., 1998; Dar, 2002). We first tested pentobarbital and pregnanolone, which, depending on concentration, act as direct or allosteric agonists of most types of $\mathrm{GABA}_{\mathrm{A}}$ receptor. We found that, like ethanol, these drugs produced less ataxia in $\mathrm{PKC} \delta^{-1-}$ mice than in wild type littermates (Fig. $3 A, B$ ). Two-way, repeated measures ANOVA showed an effect of genotype $\left(F_{(1,56)}=7.04, p=0.019\right)$ and time $\left(F_{(4,56)}=5.63, p=0.007\right)$ without interaction between these factors $\left(F_{(4,56)}=1.74\right.$, NS) for pentobarbital and an effect of genotype $\left(F_{(1,56)}=5.76, p=0.031\right)$ and time $\left(F_{(4,56)}=13.68, p<\right.$ $0.001)$ without an interaction between these factors $\left(F_{(4,56)}=\right.$ 1.50 , NS) for pregnanolone. Because pentobarbital and pregnanolone act at many different subtypes of $\mathrm{GABA}_{\mathrm{A}}$ receptors, we 

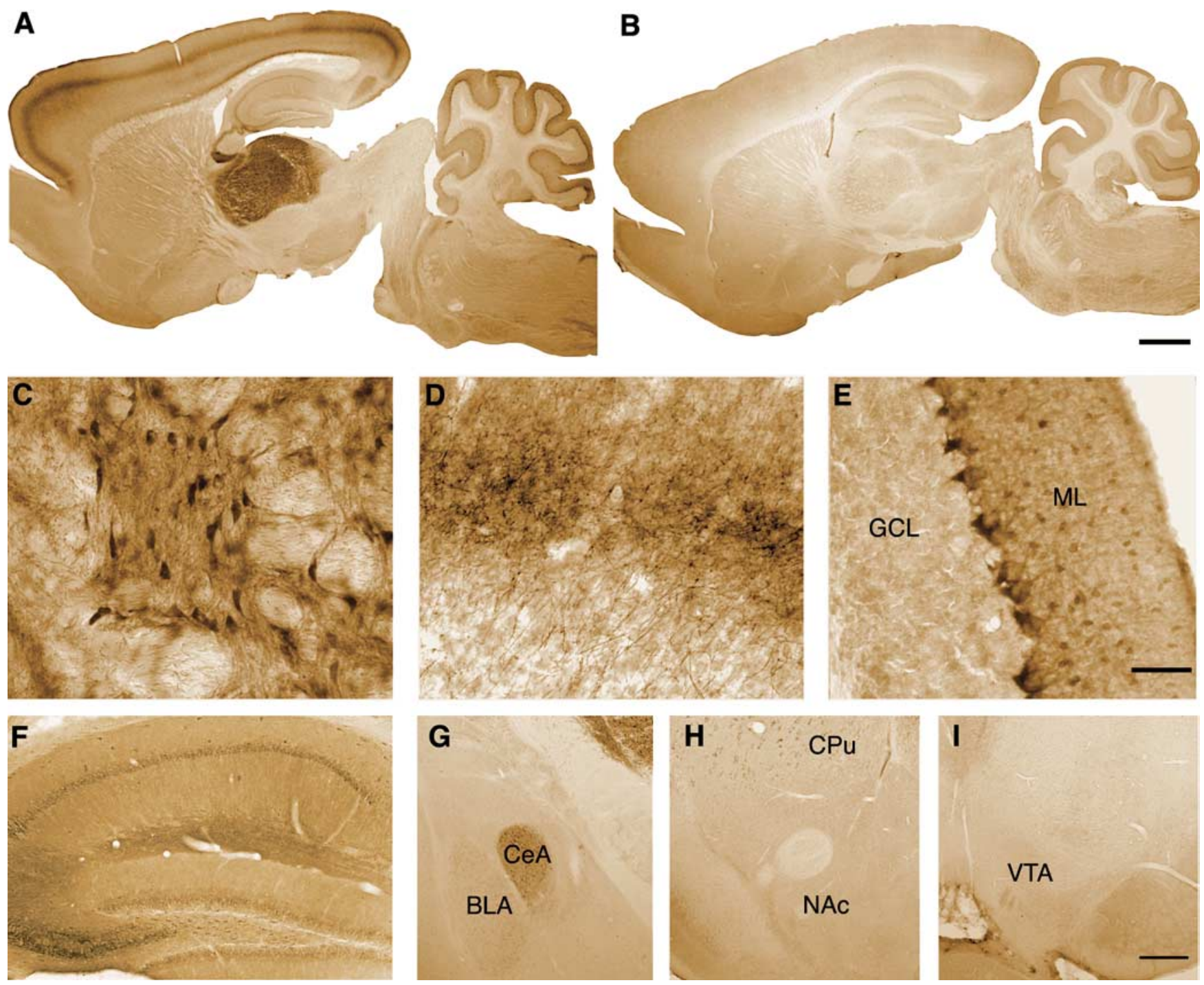

Figure 2. Expression of PKC $\delta$ in mouse brain. $\boldsymbol{A}, \boldsymbol{B}$, Immunoperoxidase staining for PKC $\delta$ immunoreactivity in sagittal brain sections from PKC $\delta^{+/+}(\boldsymbol{A})$ and PKC $\delta^{-/-}(\boldsymbol{B})$ mice. $\boldsymbol{C}-\boldsymbol{E}$, High-power micrographs of $(\boldsymbol{C})$ thalamus, $(\boldsymbol{D})$ thalamocortical fibers in layer IV of cerebral cortex, and $(\boldsymbol{E})$ cerebellar cortex from a PKC $\delta^{+/+}$mouse. ML, Molecular layer; GCL, granule cell layer. $\boldsymbol{F}$, $G$, PKC $\delta$ immunoreactivity was moderate in cell bodies of pyramidal neurons, dentate gyrus granule cells and molecular layer interneurons of the hippocampus $(\boldsymbol{F})$, and in the central amygdala (CeA) (G). $\boldsymbol{H}, \boldsymbol{I}$, Scattered PKC $\delta$ immunoreactivity was observed in the caudate-putamen (CPu), but none was observed in the nucleus accumbens (NAc) or the ventral tegmental area (VTA). Scale bars: (in B) $A, B, 1 \mathrm{~mm}$; (in $\boldsymbol{E}) \boldsymbol{C}-\boldsymbol{E}, 50 \mu \mathrm{m}$; (in I) $\boldsymbol{F}-\boldsymbol{I}, 250 \mu \mathrm{m}$.

also examined the response to the classical benzodiazepine flunitrazepam, which acts as a positive allosteric modulator only at receptors containing $\gamma 2$ subunits together with $\alpha 1, \alpha 2, \alpha 3$ or $\alpha 5$ subunits (Mehta and Ticku, 1999). In contrast to pentobarbital, pregnanolone and ethanol, $2 \mathrm{mg} / \mathrm{kg}$ flunitrazepam (Fig. 3C) produced similar responses in both genotypes $\left[F_{(1,120)}(\right.$ genotype $)=$ 0.005 , NS; $F_{(4,120)}($ time $)=50.25, p<0.0001 ; F_{(4,120)}$ (genotype $\times$ time $)=0.249, \mathrm{NS}$ ]. This pattern of responses suggests that $\mathrm{PKC} \delta$ regulates a subset of $\mathrm{GABA}_{\mathrm{A}}$ receptors that are not benzodiazepine-sensitive.

Ethanol inhibition of NMDA receptors has also been implicated in ethanol-induced ataxia (Khanna et al., 1995; Dar, 2002). Therefore, we investigated whether $\mathrm{PKC} \delta^{-l-}$ mice show less ataxia in response to NMDA receptor antagonists. We found that the response to the noncompetitive NMDA receptor antagonist ketamine $(50 \mathrm{mg} / \mathrm{kg}$; Fig. $3 D)$ was similar in both genotypes $\left[F_{(1,56)}(\right.$ genotype $)=0.895, \mathrm{NS} ; F_{(4,56)}($ time $)=63.97, p<0.001$; $F_{(4,56)}($ genotype $\times$ time $\left.)=2.47, \mathrm{NS}\right]$. Because ketamine also modulates $\mathrm{GABA}_{\mathrm{A}}$ receptors, we tested a second noncompetitive
NMDA receptor antagonist, $M K 801$ which does not alter $\mathrm{GABA}_{\mathrm{A}}$ receptor function (Hevers et al., 2008). Ataxia induced by MK$801(0.5 \mathrm{mg} / \mathrm{kg}$; Fig. $3 E)$, was also similar between the genotypes $\left[F_{(1,52)}(\right.$ genotype $)=0.002, \mathrm{NS} ; F_{(4,52)}($ time $)=24.63, p<0.001$; $F_{(4,52)}($ genotype $\times$ time $)=1.29$, NS $]$.

\section{Colocalization of PKC $\delta$ with $\alpha 4$ and $\delta$ subunits of $\mathrm{GABA}_{\mathrm{A}}$ receptors}

Because $\mathrm{PKC} \delta^{-1-}$ mice showed a diminished response to pentobarbital and pregnanolone, which act at most $\mathrm{GABA}_{\mathrm{A}}$ receptors, but not to the benzodiazepine flunitrazepam which acts at the majority of receptors that contain $\gamma 2$ subunits, we postulated that PKC $\delta$ regulates $\mathrm{GABA}_{\mathrm{A}}$ receptors that lack $\gamma 2$ subunits. The most abundant of these receptors are those that contain $\delta$ subunits, which combine mainly with $\alpha 4$ or $\alpha 6$ subunits to form receptors that mediate tonic inhibitory currents in neurons (Farrant and Nusser, 2005). Analysis of expression patterns for PKC $\delta$ in mice (Fig. 2) and for $\alpha 4$ and $\delta \mathrm{GABA}_{\mathrm{A}}$ receptor subunits in the rat (Pirker et al., 2000) suggested that these proteins should overlap 
in the mouse thalamus and hippocampus. We confirmed this prediction by incubating sagittal brain sections with antibodies against PKC $\delta$ and $\alpha 4$ (Fig. $4 A$ ) or $\delta$ (Fig. $4 B) \mathrm{GABA}_{\mathrm{A}}$ receptor subunits. In contrast, in the cerebellum, PKC $\delta$ immunoreactivity was present in the molecular and Purkinje cell layers of the cortex and did not overlap with immunoreactivity to $\mathrm{GABA}_{\mathrm{A}}$ $\delta$ (Fig. $4 C$ ) or $\mathrm{GABA}_{\mathrm{A}} \alpha 6$ (data not shown) subunits, which were expressed instead in the granule cell layer.

\section{Ethanol enhancement of tonic inhibitory currents in thalamic neurons and dentate gyrus granule cells}

These histological findings raised the possibility that $\mathrm{PKC} \delta$ regulates tonic GABA currents in brain regions that regulate motor function in which $\mathrm{PKC} \delta$ expression overlaps with $\mathrm{GABA}_{\mathrm{A}} \alpha 4$ and $\delta$ subunits. To investigate this hypothesis, we performed whole cell voltage clamp recordings on thalamic relay neurons because they express high levels of PKC $\delta$ and $\mathrm{GABA}_{\mathrm{A}} \alpha 4$ and $\delta$ subunits and because the thalamus participates in neuronal circuits that control coordinated movement. The input resistances were similar $(p<0.05)$ in $\mathrm{PKC} \delta^{+/+}(168.4 \pm$ $8.8 \mathrm{M} \Omega)$ and $\mathrm{PKC} \delta^{-1-}(164.1 \pm 12.1 \mathrm{M} \Omega)$ neurons. In mice, intraperitoneal injection of $1.5 \mathrm{~g} / \mathrm{kg}$ ethanol yields a peak blood ethanol concentration of $200-240 \mathrm{mg} / \mathrm{dl}(43-52 \mathrm{~mm})$ within 10 min which falls to $\sim 150 \mathrm{mg} / \mathrm{dl}(32 \mathrm{mM}$ ) after $60 \mathrm{~min}$ (Gentry et al., 1983). Therefore, to conservatively approximate the blood ethanol concentrations achieved during our studies of ethanolinduced ataxia, we examine the effects of $30 \mathrm{~mm}$ ethanol on tonic inhibitory currents. Addition of $30 \mathrm{~mm}$ ethanol enhanced the tonic GABA current in thalamic relay neurons from wild type mice, but not from $\mathrm{PKC} \delta^{-1-}$ mice $\left[F_{(1,16)}\right.$ (genotype $)=0.1, \mathrm{NS}$; $F_{(1,16)}($ treatment $)=51.23, p<0.0001 ; F_{(1,16)}($ genotype $\times$ treatment) $=21.49, p=0.0003$ ] (Fig. 5A-C). To confirm this result, we examined neurons in another brain region, the hippocampal dentate gyrus, at which we have previously identified ethanolsensitive tonic currents (Wei et al., 2004; Glykys et al., 2007). As in thalamic neurons, input resistances were similar $(p<0.05)$ in $\mathrm{PKC} \delta^{+/+}(151.2 \pm 13.3 \mathrm{M} \Omega)$ and $\mathrm{PKC} \delta^{-/-}(155.1 \pm 15.2 \mathrm{M} \Omega)$ dentate gyrus granule cells. Similar to thalamic relay neurons, ethanol enhanced the tonic GABA current in hippocampal dentate gyrus granule cells from $\mathrm{PKC} \delta^{+/+}$mice, but not from $\mathrm{PKC} \delta^{-1-}$ mice (Fig. $\left.5 D\right)\left[F_{(1,14)}\right.$ (genotype) $=1.35$, NS; $F_{(1,14)}$ (treatment) $=30.43, p<0.0001 ; F_{(1,14)}$ (genotype $\times$ treat ment $)=19.85, p=0.0005]$. This concentration of ethanol did not alter phasic GABA inhibitory postsynaptic currents in thalamic relay neurons (supplemental Fig. 2, supplemental Table 1, available at www.jneurosci.org as supplemental material) or hippocampal neurons (Wei et al., 2004; Glykys et al., 2007).

Recently we found that ethanol increases tonic currents in interneurons that reside within the molecular layer (ML) of the dentate gyrus (Glykys et al., 2007). The tonic inhibitory current in these neurons is mediated by $\mathrm{GABA}_{\mathrm{A}}$ receptors that contain $\delta$ subunits and $\alpha 1$ rather than $\alpha 4$ subunits, indicating that $\delta$ subunits are critical for ethanol enhancement of the tonic inhibitory current. To determine whether only $\delta$ subunits are required for
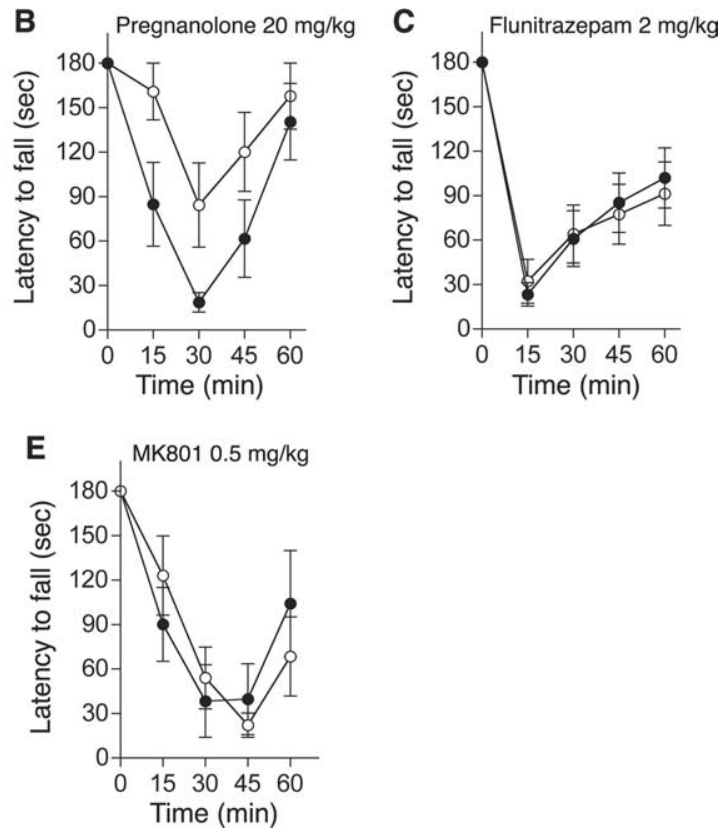

Figure 3. $\boldsymbol{A}-\boldsymbol{E}$, Ataxia induced by drugs that act at $G A B A_{A}$ and $N M D A$ receptors. Mice were tested for their ability to remain for $(\boldsymbol{A})$, pregnanolone $(\boldsymbol{B})$, flunitrazepam $(\boldsymbol{C})$, ketamine $(\boldsymbol{D})$, or MK-801 $(\boldsymbol{E}) . n=8(\boldsymbol{A}, \boldsymbol{B}, \boldsymbol{D})$ and $n=16(\boldsymbol{C})$ for each genotype. $\ln \boldsymbol{E}, n=$ 7 for $\operatorname{PKC} \delta^{+/+}$and $n=8$ for $\operatorname{PKC} \delta^{-/-}$mice.

the permissive effect of PKC $\delta$ on the response to ethanol, we examined tonic currents in ML interneurons from wild type and $\mathrm{PKC} \delta^{-1-}$ mice. Again, ethanol enhanced the tonic current (Fig. $5 E$ ) in ML interneurons from wild type mice but not from $\mathrm{PKC} \delta^{-1-}$ mice $\left[F_{(1,12)}\right.$ (genotype) $=0.48$, NS; $F_{(1,12)}$ (treatment $)=13.39, p=0.0033 ; F_{(1,14)}($ genotype $\times$ treatment $)=$ $7.20, p=0.0199]$. This result indicates that PKC $\delta$ modulation of ethanol sensitivity requires the presence of $\mathrm{GABA}_{\mathrm{A}} \delta$ subunits but not of $\alpha 4$ subunits.

\section{PKC $\delta$ regulates ethanol enhancement of GABA-stimulated current carried by $\alpha 4 \beta 3 \delta$ receptors}

Because PKC $\delta$ appeared necessary for ethanol enhancement of tonic GABA currents, we investigated whether PKC $\delta$ acts directly on $\mathrm{GABA}_{\mathrm{A}}$ receptors that contain $\delta$ subunits by using mouse $\mathrm{L}\left(\mathrm{tk}^{-}\right.$) fibroblasts that stably express $\alpha 4 \beta 3 \delta$ receptors (Brown et al., 2002). GABA-stimulated currents in these cells have been reported to be insensitive to ethanol at concentrations of $100 \mathrm{~mm}$ or less (Borghese et al., 2006). Suspecting that the abundance of PKC $\delta$ might be low in $\alpha 4 \beta 3 \delta$-expressing $\mathrm{L} \mathrm{tk}^{-}$) cells, we measured PKC $\delta$ levels relative to other cell lines. We found that PKC $\delta$ immunoreactivity was $>50 \%$ lower in $\mathrm{L}\left(\mathrm{tk}^{-}\right)$cells compared with $\mathrm{CHO}$ or HEK-293 cells (Fig. 6A).

We next investigated whether the low abundance of PKC $\delta$ might limit the response to ethanol in $\alpha 4 \beta 3 \delta$-expressing $\mathrm{L}\left(\mathrm{tk}^{-}\right)$ cells. To test this hypothesis we increased the abundance of PKC $\delta$ in these cells by stably transfecting them with as-PKC $\delta$, which is an ATP analog-sensitive mutant of PKC $\delta$ (Allen et al., 2007). The advantage of expressing as-PKC $\delta$ instead of native PKC $\delta$ is that as-PKC $\delta$ can be inhibited with high specificity by compounds that do not inhibit native kinases. The resulting stable cell line expressed PKC $\delta$ immunoreactivity that was $>2$-fold greater than the parent cell line (Fig. $6 \mathrm{~B}$ ). We then compared the effect of ethanol on $\mathrm{GABA}_{\mathrm{A}}$ currents in the parent $\alpha 4 \beta 3 \delta$-expressing cell line and the cell line stably transfected with as-PKC $\delta$. In the parent cell line, ethanol increased currents evoked by an $\mathrm{EC}_{20}$ con- 


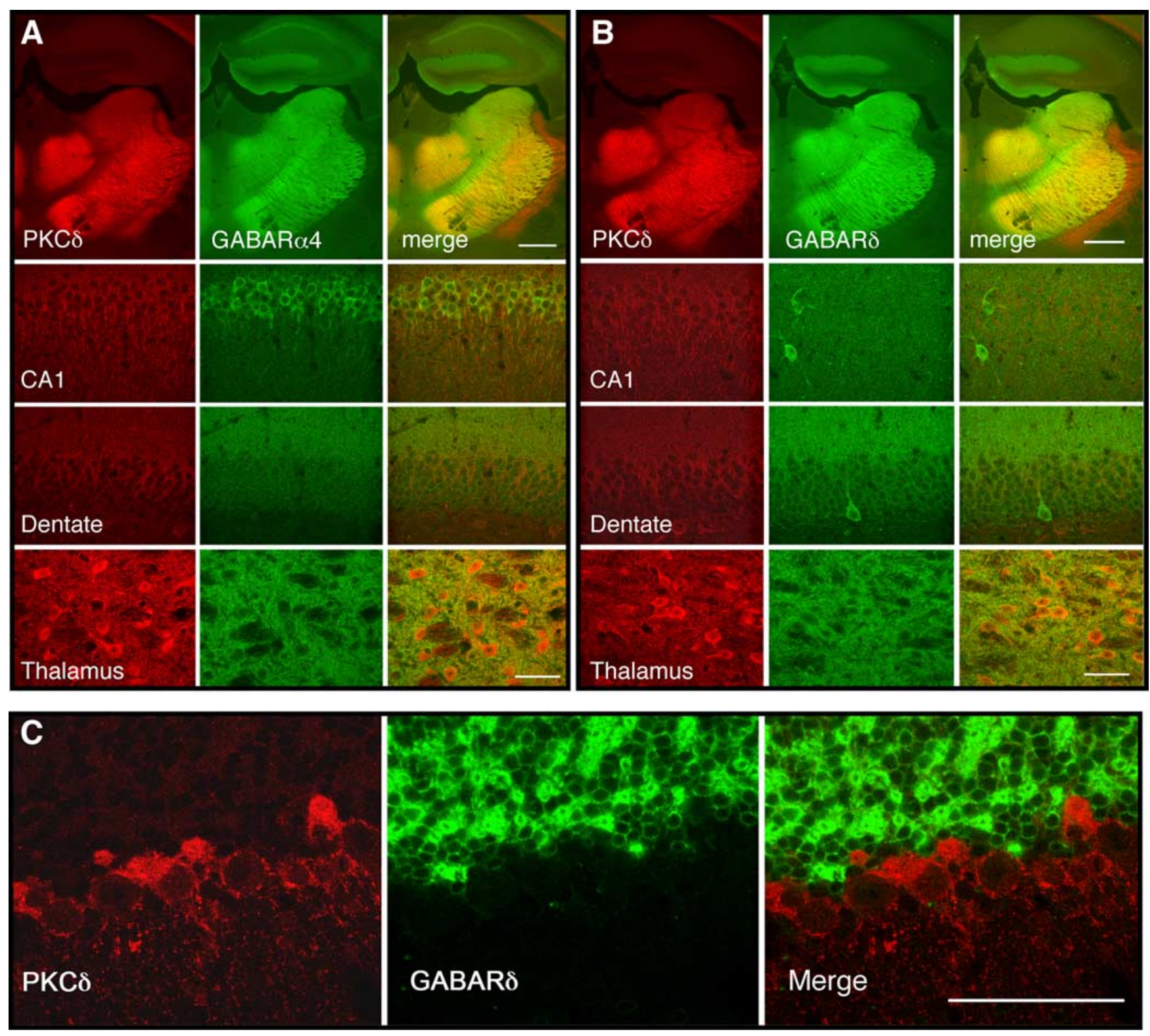

Figure 4. Colocalization of $\mathrm{GABA}_{A} \alpha 4$ and $\delta$ subunit immunoreactivity with PKC $\delta$ in mouse brain. $A$, Coronal sections through the hippocampus and thalamus showing immunoreactivity for PKC $\delta$ (red), $\alpha 4$ subunits (green), and their colocalization (yellow) in hippocampus and thalamus. $\boldsymbol{B}$, Similar sections showing immunoreactivity for PKC $\delta$ (red), $\delta$ subunits (green), and their colocalization (yellow) in hippocampus and thalamus. C, Sections of cerebellar cortex showing PKC $\delta$ immunoreactivity in the Purkinje cell and molecular layers, which did not colocalize with $\delta$ subunit immunoreactivity present in the granule cell layer. Scale bars: $A, B, 500 \mu \mathrm{m}$ for low-power images, $50 \mu \mathrm{m}$ for high-power images; $C, 50 \mu \mathrm{m}$.

centration $(0.1 \mu \mathrm{M})$ of GABA (Fig. $6 C, D)\left(F_{(5,60)}=28.16 ; p<\right.$ $0.0001)$. This effect was significant at $3-100 \mathrm{~mm}$ ethanol compared with current evoked by GABA alone ( $p<0.05$ by Dunnett's test). Enhancement of GABA currents by ethanol was significantly greater in as-PKC $\delta$-transfected cells than in the parent cell line (Fig. 6C,D). Two-way ANOVA revealed main effects of cell line $\left(F_{(1,97)}=40.77, p<0.0001\right)$ and ethanol concentration $\left(F_{(5,97)}=26.39, p<0.0001\right)$ with a significant interaction between these factors $\left(F_{(5,97)}=2.76, p<0.0226\right)$.

Based on experience with other ATP analog-sensitive kinase mutants, we predicted that as-PKC $\delta$ would be sensitive to analogs of the general kinase inhibitor 4-amino-5-(4methylphenyl)-7-(t-butyl)pyrazolo[3,4-d]pyrimidine (PP1). In vitro kinase assays with enzyme expressed and purified from COS-7 cells showed that, unlike wild-type PKC $\delta$, as-PKC $\delta$ is inhibited by nanomolar concentrations of 1-naphthyl-PP1
$(1 \mathrm{NaPP} 1)$ (Fig. $6 E$ ). In cells expressing as-PKC $\delta, 30 \mathrm{~mm}$ ethanol (Fig. 6 F) reversibly enhanced the GABA current by $47 \pm 6 \%$ ( $n=$ $10)$, whereas treatment with $10 \mu \mathrm{M} 1 \mathrm{NaPP} 1$ significantly reduced enhancement by ethanol to $21 \pm 5 \%(n=4 ; p=0.019$ by twotailed, $t$ test). $1 \mathrm{NaPP} 1$ did not alter the $\mathrm{EC}_{50}$ for GABA in asPKC $\delta$-transfected cells treated with GABA alone (data not shown). These findings demonstrate that $\mathrm{PKC} \delta$ increases the sensitivity of $\alpha 4 \beta 3 \delta \mathrm{GABA}_{\mathrm{A}}$ receptors to ethanol.

\section{Discussion}

In this study we found that $\mathrm{PKC} \delta^{-1-}$ mice show reduced signs of acute ethanol intoxication compared with wild type littermates. Particularly striking was the resistance of $\mathrm{PKC} \delta^{-/-}$mice to ethanol-induced ataxia, suggesting that $\mathrm{PKC} \delta$ residing in neural systems that regulate coordination is important for the motorimpairing effects of ethanol. This conclusion is supported by the 
finding that $\mathrm{PKC} \delta$ is highly expressed in neurons of the ventral thalamus and cerebellar cortex, and in thalamocortical efferents to the cerebral cortex, which all contribute to circuits that control movement.

Because GABA (Lüddens et al., 1990; Fidecka and Langwínski, 1995; Grobin et al., 1998) and NMDA (Khanna et al., 1995; Dar, 2002) receptors are implicated in ethanol-induced ataxia, we examined whether responses to drugs that act at these receptors are altered in $\mathrm{PKC} \delta^{-1-}$ mice. We found a decrease in the ataxic response to pentobarbital and pregnanolone, suggesting that $\mathrm{PKC} \delta$ modulates ethanol's effects at $\mathrm{GABA}_{\mathrm{A}}$ receptors in central motor circuits that control coordination. Our finding that ataxia induced by flunitrazepam was not altered in PKC $\delta^{-1-}$ mice suggested that PKC $\delta$ selectively modulates $\mathrm{GABA}_{\mathrm{A}}$ receptors that are benzodiazepine insensitive, the majority of which contain $\delta$ subunits and are extrasynaptic. In contrast, we found no difference between $\mathrm{PKC} \delta^{+/+}$and $\mathrm{PKC} \delta^{-/-}$ mice in their ataxic response to administration of ketamine or MK-801, suggesting that $\mathrm{PKC} \delta$ does not regulate the effect of ethanol at NMDA receptors.

Our analysis of brain expression patterns for $\mathrm{PKC} \delta$, and $\alpha 4, \alpha 6$ and $\delta \mathrm{GABA}_{\mathrm{A}}$ subunits revealed that $\mathrm{PKC} \delta$ overlaps with expression of $\alpha 4$ and $\delta$ subunits. This overlap was most striking in the thalamus, lesions of which can produce ataxia in humans (Melo et al., 1992). Because recent evidence indicates that $\mathrm{GABA}_{\mathrm{A}}$ receptors containing $\alpha 4$ and $\delta$ subunits mediate tonic inhibition in thalamic relay neurons (Cope et al., 2005; Jia et al., 2005), we investigated whether ethanol enhancement of tonic GABA current was diminished in thalamic relay neurons from $\mathrm{PKC} \delta^{-1-}$ mice. We found that tonic GABA currents in thalamic relay neurons are increased by ethanol to a much greater extent in cells from wild type mice compared with $\mathrm{PKC} \delta^{-1-}$ mice. We also examined hippocampal dentate gyrus granule cells because they too exhibit ethanolsensitive tonic currents that are carried by $\alpha 4 / \delta$-containing $\mathrm{GABA}_{\mathrm{A}}$ receptors (Mtchedlishvili and Kapur, 2006). Again, ethanol (30 mM) increased tonic GABA currents in cells from wild type but not from $\mathrm{PKC} \delta^{-/-}$mice. Finally, we examined ML interneurons because they express ethanol-sensitive tonic currents mediated by $\alpha 1 / \delta$ - rather than $\alpha 4 / \delta$-containing $\mathrm{GABA}_{\mathrm{A}}$ receptors (Glykys et al., 2007). Again, we found that ethanol enhanced the tonic current in neurons from wild type, but not from $\mathrm{PKC} \delta^{-/-}$mice. Together, these results indicate that in several populations of neurons, $\mathrm{PKC} \delta$ is necessary for ethanol enhancement of tonic GABA currents mediated by extrasynaptic receptors that contain $\mathrm{GABA}_{\mathrm{A}} \delta$ subunits.

Tonic currents are stimulated by extracellular concentrations of GABA, which are regulated by the activity of GABA transporters on neurons and glia, and by spillover from GABA released at synapses (Farrant and Nusser, 2005). Therefore, PKC $\delta$ could al- ter tonic GABA currents by regulating the ethanol sensitivity of $\mathrm{GABA}_{\mathrm{A}} \delta$-containing receptors, or by altering GABA transport. Our studies with $\mathrm{L}\left(\mathrm{tk}^{-}\right)$cells that express $\alpha 4 \beta 3 \delta$ receptors, however, showed that overexpression of $\mathrm{PKC} \delta$ facilitates ethanol enhancement of GABA-stimulated current whereas inhibition of $\mathrm{PKC} \delta$ diminishes this response. These findings clearly demonstrate that $\mathrm{PKC} \delta$ regulates the response of $\delta$ subunit-containing receptors to ethanol and suggest that $\mathrm{PKC} \delta$ phosphorylates $\mathrm{GABA}_{\mathrm{A}}$ receptor $\delta$ subunits or another protein that regulates receptor function. Our findings do not eliminate the possibility that $\mathrm{PKC} \delta$ also regulates GABA transport, but we do not think this could be important for the response of tonic currents to ethanol, because we still observe ethanol enhancement of tonic current in the presence of the GABA transport inhibitor NO-711 (Glykys et al., 2007).

Several laboratories report that intoxicating concentrations of ethanol $\leq 50 \mathrm{mM}$ enhance $\mathrm{GABA}_{\mathrm{A}}$ currents carried by receptors containing $\delta$ subunits (Sundstrom-Poromaa et al., 2002; Wallner et al., 2003; Wei et al., 2004; Jia et al., 2008; Liang et al., 2008). However, some investigators cannot reproduce these findings (Borghese et al., 2006; Yamashita et al., 2006) or find that ethanol 
A

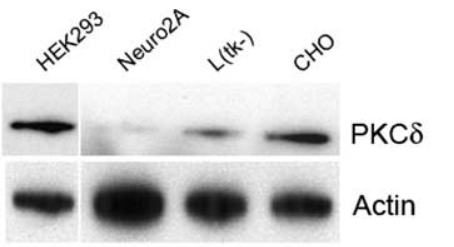

B
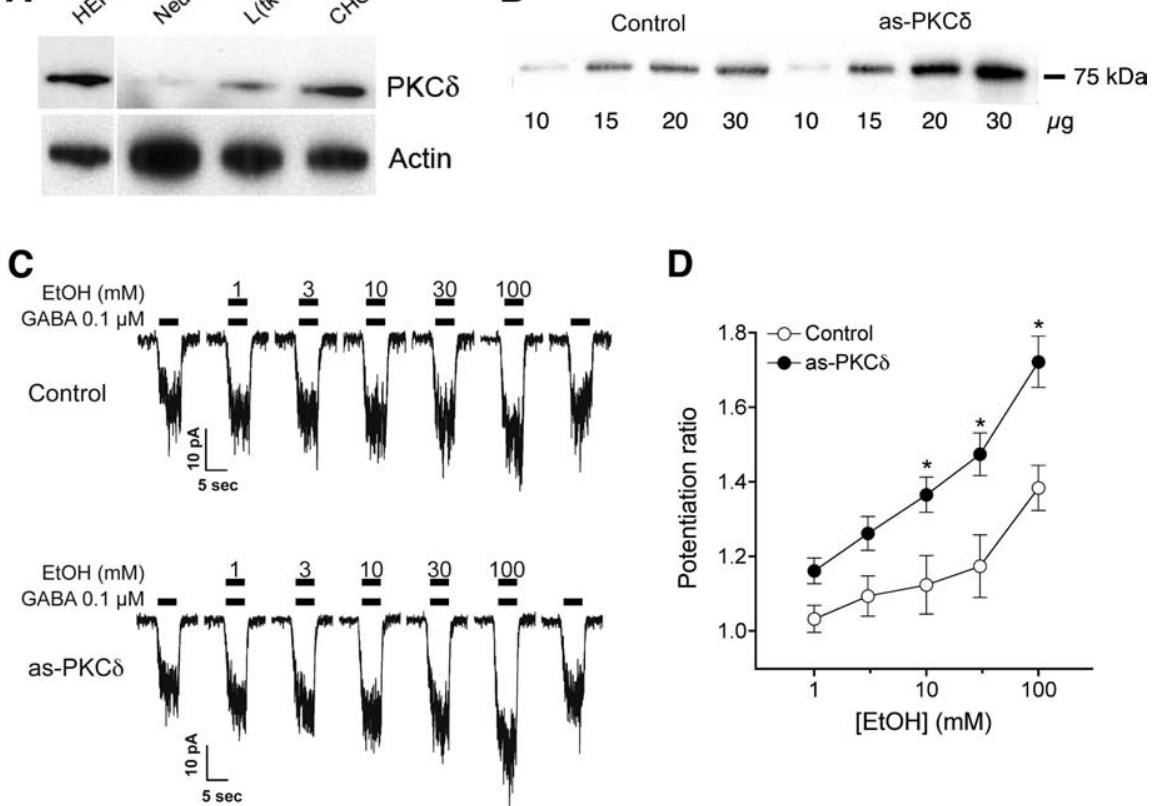

D

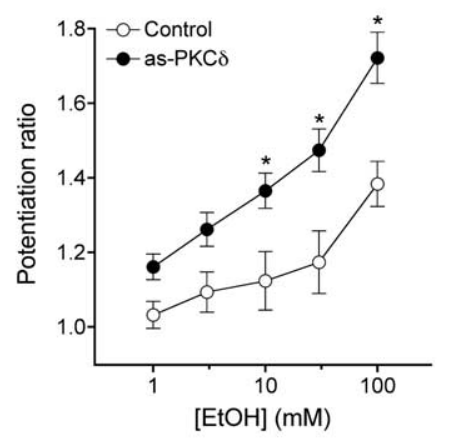

$\mathbf{E}$

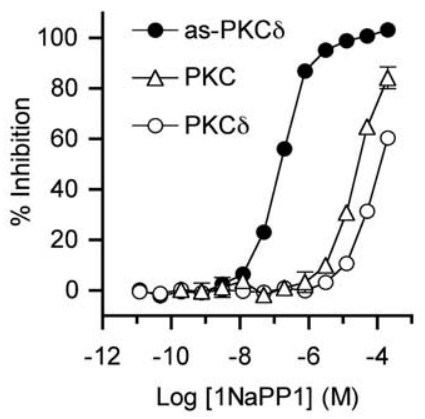

F
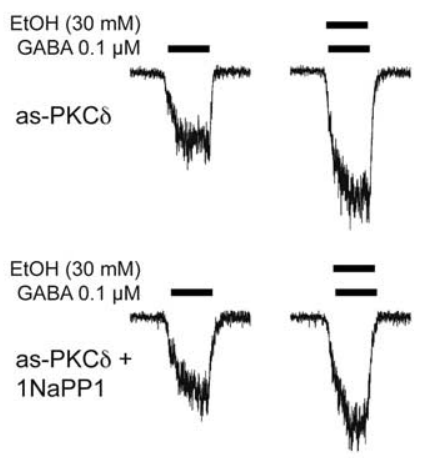

Figure 6. PKC $\delta$ regulates ethanol sensitivity of $\alpha 4 \beta 3 \delta \mathrm{GABA}_{\mathrm{A}}$ receptors expressed in $\mathrm{L}\left(\mathrm{tk}^{-}\right)$cells. $\boldsymbol{A}$, Western blot analysis of PKC $\delta$ and actin immunoreactivity in HEK293, Neuro2A, $\left.\mathrm{L}_{(\mathrm{tk}}{ }^{-}\right)$, and $\mathrm{CHO}$ cells showing less PKC $\delta$ abundance in $\mathrm{L}^{\left(\mathrm{tk}^{-}\right.}{ }^{-}$) cells relative to actin when compared with $\mathrm{CH} 0$ and HEK293 cells. $\boldsymbol{B}$, Western blot showing overexpression of PKC $\delta$ in L(tk $\left.{ }^{-}\right)$cells after transfection with as-PKC $\delta$. C, D, Ethanol enhancement of $\mathrm{EC}_{20} \mathrm{GABA}$-stimulated currents in $\mathrm{L}$ (tk ${ }^{-}$) cells that express $\alpha 4 \beta 3 \delta$ receptors. ${ }^{*} p<0.05$ compared with cells not transfected with as-PKC $\delta$ at the same concentration of ethanol by Bonferroni tests. $\boldsymbol{E}$, Inhibition of as-PKC $\delta$, a commercial mixture of PKC isozymes (PKC) (Calbiochem) and wild-type PKC $\delta$ by the PP1 analog $1 \mathrm{NaPP1}$. Nonlinear regression analysis showed significant differences $(<0.0001)$ between $\log \mathrm{EC}_{50}$ values $(\mathrm{M})$ for $1 \mathrm{NaPP1}$ inhibition of as-PKC $\delta(-6.81 \pm 0.02)$ versus wild type PKC $\delta(-4.06 \pm 0.04)$ or the mixture of PKC isozymes $(-4.59 \pm 0.04)$. $F, \mathrm{~L}\left(\mathrm{tk}^{-}\right)$cells that express $\alpha 4 \beta 3 \delta$ receptors and as-PKC $\delta$ were treated with $0.1 \mu \mathrm{m}$ GABA and $30 \mathrm{~mm}$ ethanol. Ethanol reversibly enhanced the GABA-stimulated current and addition of $10 \mu \mathrm{m} 1 \mathrm{NaPP} 1$ reduced this effect of ethanol

modulation of tonic GABA currents is indirect and occurs via stimulation of GABA release rather than by a direct effect on extrasynaptic receptors (Carta et al., 2004). These discrepant results may be due to differences in expression systems, experimental technique, or the age of the animals tested. However, our present results suggest that negative results can also be due to absent or decreased PKC $\delta$ activity in some model systems.

Our findings add to a growing body of literature that describes the role of PKC in regulating GABA signaling. Two other PKC isozymes, $\mathrm{PKC} \gamma$ and $\mathrm{PKC} \varepsilon$, modify responses to ethanol in mice through actions at $\mathrm{GABA}_{\mathrm{A}}$ receptors. $\mathrm{PKC} \gamma^{-1-}$ mice show reduced ethanol-induced LORR and hypothermia (Harris et al., 1995), whereas $\mathrm{PKC} \varepsilon^{-1-}$ mice show an increased duration of the ethanol-induced LORR (Hodge et al., 1999; Choi et al., 2002). Likewise, ethanol enhancement of $\mathrm{GABA}_{\mathrm{A}}$ receptor function is reduced in $\mathrm{PKC} \gamma^{-1-}$ mice but increased in PKC $\varepsilon^{-I-}$ mice (Harris et al., 1995; Hodge et al., 1999; Proctor et al., 2003). We re-
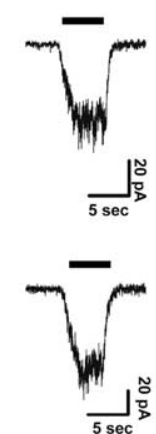

cently found that $\mathrm{PKC} \varepsilon$ regulates the ethanol sensitivity of synaptic $\mathrm{GABA}_{\mathrm{A}}$ receptors through phosphorylation of $\mathrm{GABA}_{\mathrm{A}} \gamma 2$ subunits at S327 (Qi et al., 2007). The mechanism by which PKC $\gamma$ regulates $\mathrm{GABA}_{\mathrm{A}}$ sensitivity to ethanol is not yet known. Despite the widespread distribution of $\gamma 2$ subunits in the brain, $\mathrm{PKC} \varepsilon$ regulation of $\mathrm{GABA}_{\mathrm{A}}$ receptors is not evident in all brain regions. In the central amygdala, for example, we recently found that ethanol enhances GABA release rather than $\mathrm{GABA}_{\mathrm{A}}$ receptor function through a process that requires $\mathrm{PKC} \varepsilon$ (Bajo et al., 2008). Thus PKC $\varepsilon$ can regulate ethanol's effects on GABA systems in different brain regions through modulation of ethanol-induced GABA release or ethanol enhancement of $\mathrm{GABA}_{\mathrm{A}}$ receptor function.

Given the importance of PKC $\gamma$ and $\mathrm{PKC} \varepsilon$ in regulating ethanol's effects on GABA systems, we considered whether the phenotypes we observed in $\mathrm{PKC} \delta^{-1-}$ mice are due to altered expression of PKC $\gamma$ or $\mathrm{PKC} \varepsilon$. We found that the levels of $\mathrm{PKC} \gamma$ and $\mathrm{PKC} \varepsilon$ immunoreactivity are not different in brain samples from $\mathrm{PKC} \delta^{-/-}$ and $\mathrm{PKC} \delta^{+/+}$littermates (supplemental Fig. 3, available at www.jneurosci.org as supplemental material). We also measured the abundance of $\mathrm{GABA}_{\mathrm{A}} \alpha 4$ and $\delta$ subunits because tonic GABA currents in $\mathrm{PKC} \delta^{-1-}$ mice were not enhanced by ethanol. We found their abundance to be similar in cortex, thalamus, cerebellum, and hippocampus of both genotypes (supplemental Fig. 3, available at www. jneurosci.org as supplemental material). Finally, we measured the abundance of other PKC isozymes present in brain and found no differences between the genotypes (supplemental Fig. 3, available at www.jneurosci.org as supplemental material). Therefore, it is unlikely that the present results are due to indirect effects of other PKC isozymes or altered expression of $\mathrm{GABA}_{\mathrm{A}} \alpha 4$ and $\delta$ subunits; instead they reflect an effect of PKC $\delta$ on $\mathrm{GABA}_{\mathrm{A}}$ receptor function.

$\mathrm{PKC} \delta^{-1-}$ mice did not show abnormalities in gross neuroanatomy, brain histology or baseline coordination, strength, or open field activity. The lack of altered brain structure and baseline motor function makes it unlikely that the diminished acute response to ethanol in $\mathrm{PKC} \delta^{-1-}$ mice is due to major developmental changes resulting from gene deletion. There is a possibility that differences in behavior between hybrid C57BL/6J $\times$ $129 \mathrm{X} 1 / \mathrm{SvJ}$ wild type and PKC $\delta^{-1-}$ mice could be due to effects of $129 \mathrm{X} 1 / \mathrm{SvJ}$ alleles surrounding the PKC $\delta$ locus that are present in the knock-out but not in the wild type population. However, C57BL/6J and 129X1/SvJ mice do not differ in their ataxic response to volatile anesthetics, and the duration of the LORR induced by $3.5 \mathrm{~g} / \mathrm{kg}$ ethanol is $25 \%$ longer in $129 \mathrm{X} 1 / \mathrm{SvJ}$ mice than in C57BL/6J mice (Homanics et al., 1999). In contrast, in 
$\mathrm{PKC} \delta^{-1-}$ mice the LORR duration in response to ethanol was decreased compared with wild type littermates. Therefore, the altered behavioral responses we observed in $\mathrm{PKC} \delta^{-1-}$ mice treated with ethanol and other drugs that modulate $\mathrm{GABA}_{\mathrm{A}}$ receptors are unlikely due to effects of $129 \mathrm{X} 1 / \mathrm{Sv}$ J alleles neighboring the mutated $\mathrm{PKC} \delta$ locus.

In summary, our study provides novel evidence for a $\mathrm{PKC} \delta$ signal transduction pathway that enhances behavioral responses to intoxicating concentrations of ethanol achieved during social drinking in humans. This regulation occurs at least in part through PKC $\delta$ modulation of tonic inhibitory currents carried by extrasynaptic GABA receptors that contain $\delta$ subunits. The level of response to acute administration of ethanol has been proposed as a useful endophenotype for genetic studies of alcohol use disorders in humans (Schuckit, 1998; Schuckit et al., 2004). In young adult subjects with a family history of an alcohol use disorder, a low level of response to a three-drink alcohol challenge, as measured by subjective response ratings and ataxia, is associated with increased risk of developing an alcohol use disorder later in life. Our findings in $\mathrm{PKC} \delta^{-1-}$ mice, therefore, raise the possibility that identification of proteins within neuronal PKC $\delta$ signaling pathways that regulate behavioral sensitivity to ethanol and ethanol sensitivity of tonic GABA-stimulated inhibitory currents may reveal candidate genes that contribute to risk of alcohol use disorders in humans.

\section{References}

Allen JJ, Li M, Brinkworth CS, Paulson JL, Wang D, Hübner A, Chou WH, Davis RJ, Burlingame AL, Messing RO, Katayama CD, Hedrick SM, Shokat KM (2007) A semisynthetic epitope for kinase substrates. Nat Methods 4:511-516.

Bajo M, Cruz MT, Siggins GR, Messing R, Roberto M (2008) Protein kinase $\mathrm{C}$ epsilon mediation of CRF- and ethanol-induced GABA release in central amygdala. Proc Natl Acad Sci U S A 105:8410-8415.

Borghese CM, Stórustovu S, Ebert B, Herd MB, Belelli D, Lambert JJ, Marshall G, Wafford KA, Harris RA (2006) The delta subunit of gammaaminobutyric acid type A receptors does not confer sensitivity to low concentrations of ethanol. J Pharmacol Exp Ther 316:1360-1368.

Bowers BJ, Wehner JM (2001) Ethanol consumption and behavioral impulsivity are increased in protein kinase $\mathrm{C} \gamma$ null mutant mice. J Neurosci 21:RC180:1-5.

Bowers BJ, Owen EH, Collins AC, Abeliovich A, Tonegawa S, Wehner JM (1999) Decreased ethanol sensitivity and tolerance development in gamma-protein kinase $\mathrm{C}$ null mutant mice is dependent on genetic background. Alcohol Clin Exp Res 23:387-397.

Brown N, Kerby J, Bonnert TP, Whiting PJ, Wafford KA (2002) Pharmacological characterization of a novel cell line expressing human alpha(4)beta(3)delta GABA(A) receptors. Br J Pharmacol 136:965-974.

Carta M, Mameli M, Valenzuela CF (2004) Alcohol enhances GABAergic transmission to cerebellar granule cells via an increase in Golgi cell excitability. J Neurosci 24:3746-3751.

Choi DS, Wang D, Dadgar J, Chang WS, Messing RO (2002) Conditional rescue of protein kinase $\mathrm{C}$ epsilon regulates ethanol preference and hypnotic sensitivity in adult mice. J Neurosci 22:9905-9911.

Chou WH, Choi DS, Zhang H, Mu D, McMahon T, Kharazia VN, Lowell CA, Ferriero DM, Messing RO (2004) Neutrophil protein kinase Cdelta as a mediator of stroke-reperfusion injury. J Clin Invest 114:49-56.

Cope DW, Hughes SW, Crunelli V (2005) GABA A receptor-mediated tonic inhibition in thalamic neurons. J Neurosci 25:11553-11563.

Criswell HE, Breese GR (2005) A conceptualization of integrated actions of ethanol contributing to its GABAmimetic profile: a commentary. Neuropsychopharmacology 30:1407-1425.

Dar MS (1997) Mouse cerebellar adenosinergic modulation of ethanolinduced motor incoordination: possible involvement of cAMP. Brain Res 749:263-274.

Dar MS (2002) Mouse cerebellar adenosine-glutamate interactions and modulation of ethanol-induced motor incoordination. Alcohol Clin Exp Res 26:1395-1403.
Farrant M, Nusser Z (2005) Variations on an inhibitory theme: phasic and tonic activation of $\mathrm{GABA}_{\mathrm{A}}$ receptors. Nat Rev Neurosci 6:215-229.

Fidecka S, Langwínski R (1995) Ethanol and benzodiazepines. The influence of CGS 8216 on the ethanol-induced hypothermia and motor incoordination in mice and rats. J Physiol Pharmacol 46:429-437.

Fleming RL, Wilson WA, Swartzwelder HS (2007) Magnitude and ethanol sensitivity of tonic $\mathrm{GABA}_{\mathrm{A}}$ receptor-mediated inhibition in dentate gyrus changes from adolescence to adulthood. J Neurophysiol 97:3806-3811.

Gentry RT, Rappaport MS, Dole VP (1983) Serial determination of plasma ethanol concentrations in mice. Physiol Behav 31:529-532.

Glykys J, Mody I (2007) Activation of $\mathrm{GABA}_{\mathrm{A}}$ receptors: views from outside the synaptic cleft. Neuron 56:763-770.

Glykys J, Peng Z, Chandra D, Homanics GE, Houser CR, Mody I (2007) A new naturally occurring $\mathrm{GABA}(\mathrm{A})$ receptor subunit partnership with high sensitivity to ethanol. Nat Neurosci 10:40-48.

Gordon AS, Yao L, Wu ZL, Coe IR, Diamond I (1997) Ethanol alters the subcellular localization of delta- and epsilon protein kinase $\mathrm{C}$ in NG108-15 cells. Mol Pharmacol 52:554-559.

Grobin AC, Matthews DB, Devaud LL, Morrow AL (1998) The role of $\mathrm{GABA}(\mathrm{A})$ receptors in the acute and chronic effects of ethanol. Psychopharmacology 139:2-19.

Harris RA, McQuilkin SJ, Paylor R, Abeliovich A, Tonegawa S, Wehner JM (1995) Mutant mice lacking the $\gamma$ isoform of protein kinase C show decreased behavioral actions of ethanol and altered function of $\gamma$-aminobutyrate type A receptors. Proc Natl Acad Sci USA 92:3658-3662.

Hevers W, Hadley SH, Lüddens H, Amin J (2008) Ketamine, but not phencyclidine, selectively modulates cerebellar $\mathrm{GABA}_{\mathrm{A}}$ receptors containing alpha 6 and delta subunits. J Neurosci 28:5383-5393.

Hodge CW, Mehmert KK, Kelley SP, McMahon T, Haywood A, Olive MF, Wang D, Sanchez-Perez AM, Messing RO (1999) Supersensitivity to allosteric $\mathrm{GABA}_{\mathrm{A}}$ receptor modulators and alcohol in mice lacking PKC $\varepsilon$. Nat Neurosci 2:997-1002.

Homanics GE, Quinlan JJ, Firestone LL (1999) Pharmacologic and behavioral responses of Inbred C57BL/6J and strain 129/SvJ mouse lines. Pharmacol Biochem Behav 63:21-26.

Jia F, Pignataro L, Schofield CM, Yue M, Harrison NL, Goldstein PA (2005) An extrasynaptic $\mathrm{GABA}_{\mathrm{A}}$ receptor mediates tonic inhibition in thalamic VB neurons. J Neurophysiol 94:4491-4501.

Jia F, Chandra D, Homanics GE, Harrison NL (2008) Ethanol modulates synaptic and extrasynaptic $\mathrm{GABA}_{\mathrm{A}}$ receptors in the thalamus. J Pharmacol Exp Ther 326:475-482.

Khanna JM, Morato GS, Chau A, Shah G (1995) D-Cycloserine enhances rapid tolerance to ethanol motor incoordination. Pharmacol Biochem Behav 52:609-614.

Liang J, Suryanarayanan A, Chandra D, Homanics GE, Olsen RW, Spigelman I (2008) Functional consequences of $\mathrm{GABA}_{\mathrm{A}}$ receptor alpha 4 subunit deletion on synaptic and extrasynaptic currents in mouse dentate granule cells. Alcohol Clin Exp Res 32:19-26.

Lüddens H, Pritchett DB, Kohler M, Killisch I, Keinanen K, Monyer H, Sprengel R, Seeburg PH (1990) Cerebellar GABA receptor selective for a behavioural alcohol antagonist. Nature 346:648-651.

Mehta AK, Ticku MK (1999) An update on $\mathrm{GABA}_{\mathrm{A}}$ receptors. Brain Res Brain Res Rev 29:196-217.

Melo TP, Bogousslavsky J, Moulin T, Nader J, Regli F (1992) Thalamic ataxia. J Neurol 239:331-337.

Messing RO, Petersen PJ, Henrich CJ (1991) Chronic ethanol exposure increases levels of protein kinase $\mathrm{C} \delta$ and $\varepsilon$ and protein kinase $\mathrm{C}$-mediated phosphorylation in cultured neural cells. J Biol Chem 266:23428-23432.

Mtchedlishvili Z, Kapur J (2006) High-affinity, slowly desensitizing GABA receptors mediate tonic inhibition in hippocampal dentate granule cells. Mol Pharmacol 69:564-575.

Olive MF, Mehmert KK, Messing RO, Hodge CW (2000) Reduced operant ethanol self-administration and in vivo mesolimbic dopamine responses to ethanol in PKC $\varepsilon$-deficient mice. Eur J Neurosci 12:4131-4140.

Paxinos G (1995) The rat nervous system, ed 2. San Diego: Academic.

Pirker S, Schwarzer C, Wieselthaler A, Sieghart W, Sperk G (2000) GABA(A) receptors: immunocytochemical distribution of 13 subunits in the adult rat brain. Neuroscience 101:815-850.

Proctor WR, Poelchen W, Bowers BJ, Wehner JM, Messing RO, Dunwiddie TV (2003) Ethanol differentially enhances hippocampal $\mathrm{GABA}_{\mathrm{A}}$ 
receptor-mediated responses in protein kinase $\mathrm{C} \gamma(\mathrm{PKC} \gamma)$ and $\mathrm{PKC} \varepsilon$ null mice. J Pharmacol Exp Ther 305:264-270.

Qi ZH, Song M, Wallace MJ, Wang D, Newton PM, McMahon T, Chou WH, Zhang C, Shokat KM, Messing RO (2007) Protein kinase C epsilon regulates $\mathrm{GABA}_{\mathrm{A}}$ receptor sensitivity to ethanol and benzodiazepines through phosphorylation of gamma 2 subunits. J Biol Chem 282:33052-33063.

Rustay NR, Wahlsten D, Crabbe JC (2003) Influence of task parameters on rotarod performance and sensitivity to ethanol in mice. Behav Brain Res 141:237-249.

Schuckit MA (1998) Biological, psychological and environmental predictors of the alcoholism risk: a longitudinal study. J Stud Alcohol 59:485-494.

Schuckit MA, Smith TL, Kalmijn J (2004) The search for genes contributing to the low level of response to alcohol: patterns of findings across studies. Alcohol Clin Exp Res 28:1449-1458.

Stell BM, Brickley SG, Tang CY, Farrant M, Mody I (2003) Neuroactive steroids reduce neuronal excitability by selectively enhancing tonic inhibition mediated by delta subunit-containing $\mathrm{GABA}_{\mathrm{A}}$ receptors. Proc Natl Acad Sci U S A 100:14439-14444.
Sundstrom-Poromaa I, Smith DH, Gong QH, Sabado TN, Li X, Light A, Wiedmann M, Williams K, Smith SS (2002) Hormonally regulated alpha(4)beta(2)delta GABA(A) receptors are a target for alcohol. Nat Neurosci 5:721-722.

Wallner M, Hanchar HJ, Olsen RW (2003) Ethanol enhances alpha 4 beta 3 delta and alpha 6 beta 3 delta gamma-aminobutyric acid type A receptors at low concentrations known to affect humans. Proc Natl Acad Sci U S A 100:15218-15223.

Wei W, Faria LC, Mody I (2004) Low ethanol concentrations selectively augment the tonic inhibition mediated by delta subunit-containing $\mathrm{GABA}_{\mathrm{A}}$ receptors in hippocampal neurons. J Neurosci 24:8379-8382.

Weiner JL, Valenzuela CF (2006) Ethanol modulation of GABAergic transmission: the view from the slice. Pharmacol Ther 111:533-554.

Yamashita M, Marszalec W, Yeh JZ, Narahashi T (2006) Effects of ethanol on tonic GABA currents in cerebellar granule cells and mammalian cells recombinantly expressing GABA(A) receptors. J Pharmacol Exp Ther 319:431-438. 